\section{А.В. Молчанов,}

Московский государственный юридический университет имени О.Е. Кутафина,

ФАС России, г. Москва

\begin{abstract}
Аннотация
В современной России уже сложилась объективная потребность в специалистах в сфере конкурентного права и антимонопольного регулирования. Принятие соответствующего профессионального стандарта, а также включение дисциплин конкурентного права и антимонопольного регулирования в федеральные государственные образовательные стандарты является обязательным условием удовлетворения этой потребности. Проект профессионального стандарта «Специалист в сфере конкурентного права», разработанный ФАС России совместно с Ассоциацией антимонопольных экспертов и Торгово-промышленной палатой Российской Федерации, вынесен на общественное обсуждение.
\end{abstract}

Ключевые слова: развитие конкуренции, профессиональный стандарт, специалист в сфере конкурентного права.

\title{
Professional standard as an instrument of state development policy competition
}

\section{A.V. Molchanov,}

Moscow State University of Law n.a. O. Ye. Kutafin,

FAS Russia, Moscow

\section{Annotation}

In today's Russia there is an objective need for specialists in the field of competition law and antitrust regulation. Adoption of the relevant professional standard, as well as the inclusion of disciplines of competition law and antitrust regulation in federal state educational standards is a prerequisite for meeting this need. The draft professional standard "Specialist in the field of competition law", developed by the FAS Russia in conjunction with the Association of Antimonopoly Experts and the Chamber of Commerce and Industry of the Russian Federation, was submitted for public discussion.

Keywords: the development of competition, professional standard, professional in the field of competition law. 
$\mathrm{P}$ азвитие рыночных отношений предопределило основной вектор реформирования советской подсистемы права, регулирующей отношения в сфере экономики.

По утверждению В.С. Белых, принятое сегодня разделение отношений в области предпринимательства на регулируемые гражданским правом и административным иногда невозможно, многие основные институты правового регулирования экономики «...не укладываются в прокрустово ложе частного права» [1].

Специфика отношений участников товарных рынков, их особая правоспособность, особенности правовой защиты их прав и законных интересов способствовали тому, что постепенно определенные сферы правового регулирования таких отношений стали оформляться в правовые институты и отрасли права, а затем и в отрасли законодательства.

Для современного этапа антимонопольного регулирования характерно завершение процесса формирования предкодификационной общности правоотношений и правовых норм, регулирующих такие отношения [2].

По мнению А.Н. Варламовой, для решения вопроса о том, существует ли конкурентное право как отрасль законодательства, необходимо определить особый предмет регулирования конкурентного законодательства и его цель. Что касается предметного критерия, то выявление его не представляет особой трудности - предметом законодательства о конкуренции являются конкурентные отношения. Наиболее сложным является установление целей законодательства о конкуренции, которое и будет определяющим [3].

Говоря о самостоятельности конкурентного права как отрасли научного знания и как отрасли права, авторы учебника «Конкурентное право», изданного Высшей школой экономики в 2012 г., указывают, что различные толкования понятия «конкуренция» постепенно складывались в систему конкурентного права - совокупность доктринальных воззрений и юридических норм, которые обосновывают и утверждают ценность конкуренции, а также обеспечивают ее защиту и развитие [4].

К. Ю. Тотьев считает, что конкурентное право в широком понимании охватывает все нормы о развитии и защите конкуренции, содержащиеся в федеральных законах и иных нормативных правовых актах. В этом значении он включает в конкурентное право правовые нормы и институты как публично-правового, так и частноправового характера [5].

По мнению С.А. Пузыревского, предметом конкурентного права являются общественные отношения по защите и развитию конкуренции, включающие отношения по пресечению актов, действий и соглашений, приводящих к нарушению, ограничению, недопущению или устранению конкуренции, отношения по предупреждению ограничения, недопущения или устранения конкуренции, а также процедурно-процессуальные отношения по предупреждению и пресечению нарушений антимонопольного законодательства [6].

Анализируя научные подходы и действующее антимонопольное законодательство, можно сделать вывод о том, что конкурентное право направлено на регулирование экономических отношений. Эти отношения складываются между участниками гражданского оборота, положения антимонопольного законодательства направлены на обеспечение принципов гражданского права и для этих целей обладают характером публичного принуждения.

Таким образом, среди исследователей сложились подходы к необходимости определения конкурентного права в качестве самостоятельной отрасли права именно вследствие специфики отношений, на регулирование которых направлены нормы этой отрасли, и комплексности метода правового регулирования.

Об этом свидетельствуют и весьма высокие темпы появления научных и образовательных школ, специализирующихся исключительно на конкурентном праве и антимонопольном регулировании.

Так, по данным ФАС России, если по состоянию на 4 апреля 2016 г. в российских вузах действовало 19 базовых кафедр ФАС России, то на 29 марта 2017 г. таких кафедр было уже 46, а на 1 сентября 2018 г. 52. Кроме того, в академических вузах стали создаваться профильные научные подразделения (например, в Институте проблем развития науки РАН в апреле 2018 г. был создан сектор исследования проблем развития конкуренции, значительную часть которых составляют собственно правовые проблемы).

Результаты научной деятельности базовых кафедр ФАС России сегодня представлены не только многочисленными научными публикациями, но и модельными нормативными разработками, конкретными юридико-техническими решениями, которые используются ФАС России при подготовке проектов нормативных правовых актов и официальных разъяснений нормативного правового регулирования и правоприменительной практики.

В 2015 г. в ФАС России создан Научно-методический совет образовательных организаций и кафедр конкурентного права и антимонопольного регулирования, который является не только инструментом координации деятельности научных и профессиональных образовательных коллективов, но и площадкой разработки и обсуждения проектов образовательных программ. Так, на сегодня Научно-методическим советом рассмотрены и утверждены проекты 
образовательных программ по курсам «Конкурентное право», «Недобросовестная конкуренция», программа повышения квалификации по курсу «Государственное регулирование цен (тарифов)», что указывает на высокий уровень потребности государства и экономики в специалистах в сфере конкурентного права и антимонопольного регулирования.

Любое предприятие - участник рынка не может существовать вне сферы действия конкурентного права, являясь чьим-либо конкурентом, поставщиком или потребителем. Не меньшее значение антимонопольное регулирование имеет и для сферы государственного и муниципального управления (закупки товаров, работ, услуг для государственных или муниципальных нужд), и для сферы управления публичной собственностью (унитарные предприятия, распределение бюджетных субсидий и др.).

Объективно в настоящее время существует высокий спрос на специалистов в сфере конкурентного права и антимонопольного регулирования.

Следующим закономерным этапом должно стать появление соответствующего профессионального стандарта, а также появление конкурентного права и антимонопольного регулирования в федеральных государственных образовательных стандартах.

Понятия «квалификация работника» и «профессиональный стандарт» определены в ст. $195^{1}$ Трудового кодекса Российской Федерации (ТК РФ). Согласно указанной статье квалификация работника - это уровень знаний, умений, профессиональных навыков и опыта работы работника.

В свою очередь, профессиональный стандарт это характеристика квалификации, необходимой работнику для осуществления определенного вида профессиональной деятельности.

Ранее в законодательстве отсутствовало определение понятия профессионального стандарта, что затрудняло разработку и реализацию профессиональных стандартов на практике.

Появление профессиональных стандартов - это не российская новелла, а сложившаяся мировая практика. Признанный опыт внедрения профстандартов принадлежит, в частности, Великобритании.

Для работодателей профессиональный стандарт будет являться основой для установления более конкретных требований при выполнении трудовой функции работника с учетом специфики деятельности организации.

В соответствии со ст. $195^{3}$ ТК РФ, если названным кодексом, другими федеральными законами, иными нормативными правовыми актами Российской Федерации установлены требования к квалификации, необходимой работнику для выполнения определен- ной трудовой функции, профессиональные стандарты в части указанных требований обязательны для применения работодателями.

Характеристики квалификации, которые содержатся в профессиональных стандартах и обязательность применения которых не установлена в соответствии с ч. 1 ст. $195^{3}$ ТК РФ, применяются работодателями в качестве основы для определения требований к квалификации работников с учетом особенностей выполняемых работниками трудовых функций, обусловленных применяемыми технологиями и принятой организацией производства и труда.

Таким образом, профессиональные стандарты являются обязательными для применения в отношениях работодатель - работник только в том случае, если их обязательность предусмотрена каким-либо нормативным правовым актом. В ином случае они носят рекомендательный характер, но не менее важны для определения требований к работникам, определения их трудовых функций, предъявления требований и условий к образованию и повышению квалификации.

Основной характеристикой любого профессионального стандарта является обобщение профессиональных функций и определение квалификационного уровня, отвечающего этим функциям (какие трудовые функции и действия должен выполнять работник в рамках своей профессиональной сферы, какими знаниями и умениями он должен обладать). Для работодателей определяющее значение имеют: наименование той должности, по которой работник будет выполнять эти функции, требования к характеристикам профессионального образования и опыту работы, которыми должен располагать такой работник.

Не меньшее значение имеет профессиональный стандарт для разработки федеральных государственных образовательных стандартов профессионального образования, что позволяет успешно решать обострившуюся в последние годы проблему несоответствия профессиональных знаний и умений выпускника учебного заведения потребностям работодателя.

Нередко более года требуется выпускнику другой специальности, чтобы вникнуть в проблематику деятельности антимонопольного органа. При этом цена ошибки весьма высока: полномочия ведомства позволяют назначать высокие штрафы, применять другие санкции к хозсубъектам. Это оказывает большое влияние на отраслевые рынки. Поэтому необходимо организовать систему подготовки специалистов и внедрить дисциплину «конкурентное право» в федеральный государственный стандарт профессионального образования и в образовательные программы вузов [7].

Согласно п. 6 ст. 2 Федерального закона от 29.12.2012 № 273-Ф3 «Об образовании в Россий- 
ской Федерации» (далее - Закон об образовании) федеральный государственный образовательный стандарт (ФГОС) - совокупность обязательных требований к образованию определенного уровня и (или) к профессии, специальности и направлению подготовки, утвержденным федеральным органом исполнительной власти, осуществляющим функции по выработке государственной политики и нормативно-правовому регулированию в сфере образования (Минобрнауки России).

ФГОСы обязательны к применению всеми образовательными организациями России, имеющими государственную аккредитацию. Для иных учебных заведений они носят рекомендательный характер.

При этом согласно ч. 7 ст. 11 Закона об образовании формирование требований федеральных государственных образовательных стандартов профессионального образования к результатам освоения основных образовательных программ профессионального образования в части профессиональной компетенции осуществляется на основе соответствующих профессиональных стандартов (при наличии).

Связь профессиональных стандартов и образовательных стандартов важна с точки зрения соответствия деятельности системы образования запросам экономики и ее реальным потребностям, снижения неоправданных издержек при переподготовке или подготовке специалистов непосредственно на предприятии или в государственной системе управления, а также с точки зрения соответствия полученных выпускником образовательной организации знаний и умений и возможности предложить себя на рынке труда.

При этом нельзя недооценивать значение профессионального и образовательных стандартов в сфере конкурентного права для правового регулирования в целом.

Систематизация требований к профессиональным навыкам и умениям специалистов в сфере конкурентного права и антимонопольного регулирования, возможность оценки работодателями таких навыков работников при приеме на работу выпускников вузов и прохождении работниками промежуточной аттестации, возможность сформировать «специальный заказ» системе образования на специалистов в такой сфере способны стать важнейшим элементом системы адвокатирования конкуренции в целом, как части государственной политики по развитию конкуренции, повысить уровень знания антимонопольного законодательства и качества применения его на практике, что, безусловно, должно привести к повышению уровня правосознания в этой области регулирования, повышению уровня законности и снижению количества нарушений.
При этом принципиально важно обратить внимание на то, что разработка профессионального и образовательных стандартов не является сферой интересов лишь Федеральной антимонопольной службы в подготовке своих сотрудников.

«Заказ» на подготовку специалистов в сфере конкуренции и антимонопольного регулирования сегодня определяется экономикой в целом, для чего сложились условия в виде растущих кадровых потребностей экономического развития, реформы системы управления экономикой страны, развития конкуренции на товарных рынках, завершения процесса формирования конкурентного права в самостоятельные отрасли права, законодательства, научную специальность и учебную дисциплину.

Именно поэтому среди основных направлений государственной политики по развитию конкуренции в подп. «Г» п. 8 Указа Президента Российской Федерации от 21 декабря 2017 г. № 618 «Об основных направлениях государственной политики по развитию конкуренции» предусмотрена рекомендация Национальному совету при Президенте Российской Федерации по профессиональным квалификациям рассмотреть возможность создания совета профессиональных квалификаций в сфере конкурентного права и разработки соответствующего профессионального стандарта'.

Проект соответствующего профессионального стандарта «Специалист в сфере конкурентного права», разработчиками которого выступили ФАС России, Ассоциация антимонопольных экспертов и Торговопромышленная палата Российской Федерации, был рассмотрен на заседаниях Научно-методического совета образовательных организаций и кафедр конкурентного права и антимонопольного регулирования ФАС России, которые состоялись в рамках III Международной научно-практической конференции «Антимонопольная политика: наука, практика, образование. Цифровая экономика и конкурентная политика» 5-6 декабря 2017 г. в научном центре «Сколково» и во время проведения VIII Санкт-Петербургского международного юридического форума (май 2018 г.).

Проект стандарта получил одобрение и в настоящее время проходит широкое общественное обсуждение 2 для внесения его на рассмотрение Национального совета при Президенте Российской Федерации по профессиональным квалификациям.

См.: Собрание законодательства РФ. 25.12.2017. №52 (часть I). СT. 8111.

2 См., например: Стандарт «Специалист в сфере конкурентного права» // http://tpprf.ru/ru/mobile/news/regional/229892 (Дата обращения: 03.09.2018). 


\section{Литература}

1. Белых В.С. Правовое регулирование предпринимательской деятельности в России / Монография. М.: Проспект, 2009. С. 59.

2. Максимов С.В. Семь аргументов в защиту научной специальности «конкурентное право» // Российское конкурентное право и экономика. 2017. № 4. С. 6-7.

3. Варламова А.Н. Правовое обеспечение развития конкуренции / Учеб. пособие. М.: Статут, 2010. 301 c.

4. Конкурентное право России / Учебник (колл. авт.: Д. А. Алешин, И. Ю. Артемьев, Е. Ю. Борзило и др.). Отв. ред. И. Ю. Артемьев, А. Г. Сушкевич. М.: Изд. дом Высшей школы экономики, 2012. С. 15.

5. Тотьев К. Ю. Конкурентное право (правовое регулирование конкуренции) / Учебник. М.: РДЛ, 2000. С. $72-74$.

6. Пузыревский С. А. Некоторые аспекты определения отраслевой самостоятельности конкурентного права // Юрист. 2016. № 1. С. 20—26.

7. Артемьев И. Ю. Союз науки и практики - новое качество регулирования экономики // Российское конкурентное право и экономика. 2016. № 1. С. 4.

\section{Сведения об авторе}

Молчанов Артем Владимирович: преподаватель кафедры конкурентного права Московского государственного юридического университета имени О.Е. Кутафина (МГЮА), начальник Правового управления ФАС России, член Научно-методического совета ФАС России Контактная информация:

Адрес: 123995, г. Москва, ул. Садовая-Кудринская, д. 11

Тел.: +7 (499) 755-23-23

E-mail: molchanov@fas.gov.ru 